\title{
MITOLOGIAS DA CIVILIZAÇÃO INDUSTRIAL, COSMOPOLITISMO EXCLUDENTE E A IMPROVISAÇÃO DA SOBREVIVÊNCIA - SÃO PAULO 1910-1930
}

\author{
Maria Inez Machado Borges Pinto \\ Prof $^{a}$ Dr $^{a}$ do Dept ${ }^{o}$ de História/FFLCH-USP
}

\begin{abstract}
RESUMO: Este artigo pretende analisar como imagens de cunho futurista alinham-se nos vários textos dos modernistas paulistas, entre eles Mário e Oswald de Andrade, numa visão da paulicéia como ícone da modernidade brasileira. Contrapondo-se a essa visão, sobressaem algumas abordagens de Blaise Cendrars que captam as facetas contraditórias, tensas e excludentes da modernização inacabada da cidade.
\end{abstract}

PALAVRAS-CHAVE: Modernidade, Urbanização, Exclusão, Futurismo, Blaise Cendrars.

ABSTRACT This article analyses how futurist images delineate in the writings of the modernists of São Paulo, as Mário and Oswald de Andrade, a vision of the "paulicéia" as an icon of the Brazilian modernity. In opposition to this vision there are some remarks made by Blaise Cendrars that show the contradictory, tense, and excluding facets of the unfinished modernity of the city.

KEYWORDS: Modernity, Urbanization, Exclusion, Futurism, Blaise Cendrars.

O testemunho poético mais significativo sobre a cidade de São Paulo às vésperas da Semana de Arte Moderna pode ser encontrado nos versos de Luís Aranha, nos quais se aglutinam os motivos e a sintaxe de uma visão apaixonada e heróica da civilização industrial. Em suas montagens de flashes cotidianos, ritmadas pela rapidez, pela velocidade da vida citadina, sujeitas a angulações estranhas, a cortes abruptos, caracterizados por uma linguagem freqüentemente prosaica, na qual se integram, de maneira decidida, recursos derivados das modernas técnicas de comunicação de massa, configuram-se várias ima- 
gens de São Paulo, claramente revestida da dimensão do mito. Três delas são significativas por enfeixarem emblematicamente a visão que o grupo modernista tinha de São Paulo nos albores dos anos 20: a cidade tentacular ("Drogaria do Éter e de Sombra"), a cidade vertical ("Poema Giratório"), a cidade industrial ("Drogaria do Éter e de Sombra", "Crepúsculo") (ARANHA, 1984).

Estas três dimensões podem ser condensadas nos planos que articulam a visão da cidade vertical, concebida como "estrutura americana" não apenas por seu crescimento vertiginoso, mas pela presença simultânea de todas as características do processo modernizador pelo qual passava então a capital paulista. A dimensão mítica, no caso, é realçada pelo afã de inserir a sua cidade na geografia cosmopolita do "mundo eletrizado", no qual cada país se funde e se confunde numa soma de similitudes que, entretanto, capta de maneira eficaz o retrato de São Paulo moderno.

\footnotetext{
O rumor

Adivinho minha terra natal

Prédios crescendo

Andares sobre andares

Catedrais

Torres

Chaminés

O centro da cidade

Prédios como couraçados

Ancorados

Cordoalhas

Mastaréus

Flâmulas tremulando

Galhardetes dos traquetes

E a multidão frenética

Os bancos

Os jornais

As grandes casas comerciais

Bondes

Tintinabulação das campainhas

Automóveis

Buzinas

Carros carroças fragorosamente

Bairros industriais

Catadupas de som a rugir pelo espaço

Ventres de fornos colossais

Nas fábricas usinas e oficinas

Turbilhonam turbinas
}

\author{
Máquinas a mugir em movimentos loucos \\ Vozes trepidações campainhas \\ Baques gritos sereias alarido \\ Rouquejos e tropel \\ Relógios a compassar nessa luta insofrida \\ O ritmo frenético da vida!...!...(ARANHA, L., 1984 p.58-9).
}

O "Poema Giratório", datado de 1922, insere-se junto com outros versos de Aranha numa visualização prototípica da cidade de São Paulo como lugar por excelência da modernidade brasileira. O fascínio que o poeta expressa, longe da divisão perante a nova face da cidade que perpassa os poemas de Paulicéia Desvairada e Losango Cáqui, não é dessemelhante daquele que enforma a divulgação de novas idéias por parte do grupo modernista que transforma São Paulo no fulcro irradiador de um novo modo da civilização.

Imagens de cunho futurista alinham-se ao longo de inúmeros textos de propaganda das novas idéias, propondo, o mais das vezes, equação São Paulo = cidade moderna $=$ cultura nova. Numa sobreposição otimista e frequientemente acrítica, destacam-se as visões da cidade tentacular, da cidade em crescimento, da cidade industrial, da cidade acampamento, da cidade, enfim moderna, à qual não falta nenhum dos atributos exteriores que definem o processo de modernização acelerado desde o início do século XX. Para os fautores da arte nova, sequiosos de destacar o papel da Paulicéia no contexto brasileiro e, até mesmo, latino-americano, não é difícil construir um imenso caleidoscópio, uma montagem de fatos e sensações que estruturam um retrato eloqüente de um fenômeno inédito para o país. Se o Rio de Janeiro era a capital política, São Paulo configura-se nitidamente como a construção, avessa aos velhos cenários e aos velhos costumes do Brasil oitocentista e rural. É por isso que a cidade encontra expressão em imagens fortemente conotadas com a modernidade, com seus ritmos, com sua efervescência, constituindo um painel em que não há lugar para dúvidas e hesitações e sim tão-somente para a visão prospectiva, para a "vocação futurista" 
de um "povo de mil origens, arribado em mil barcos, com desastres e ânsias" (ANDRADE, 1921).

A cidade, definida pela "audácia vertical", devassada "no recorte desassombrado de suas ruas de fábricas e dos seus conjuntos de palácios americanos", revela ao olhar apaixonado dos modernistas sua feição complexa, inacabada e provisória: os "desdobramentos infindáveis de bairros nascentes", a "ambição improvisada das suas feiras", a "vitória dos seus mercados", o recorte na paisagem "das chaminés fumegantes e das ruas tumultuárias de povo", seu caráter de "metrópole febril, milionária, imprevistamente enorme" e, por isso mesmo, próxima da lógica do acampamento, do empreendimento em devir, de "cidade tentacular", de "cidade tentacular", "derramada até a várzea", na qual "o apito das fábricas e locomotivas, e o atraente rodar dos veículos no asfalto, os zumbidos dos bondes, o fonfonar dos autos, os burburinhos das turbas, criam estados de alma novos, acendem desejos, sonhos, tristezas novas".

São imagens interativas, como se pode perceber, muitas vezes retóricas em seu afã propagandístico, que não conseguem esconder uma leitura positivista do "fenômeno São Paulo", vazada no tripé tainiano raça-momento-meio. É o que se percebe, por exemplo, na análise de um intelectual não-paulista como Ronald de Carvalho, que traça um retrato do Estado de São Paulo para explicar a presença do grupo independente, assumindo como axioma tácito a idéia de que o meio é a causa da obra de arte. A figura histórica do bandeirante é transposta e aplicada aos fazendeiros, aos industriais, aos "criadores de fortuna", aos self-made, isto é, àqueles "indivíduos práticos, de gênio claro e positivo", que se erguem como contraponto aos "gramáticos e bacharéis", aos "críticos e doutores" que pululam pelo resto do país. Traçado o perfil da raça, entendida no caso como "caráter regional”, Ronald de Carvalho funde momento, raça e meio na visão das energias novas - máquina, tear, polia -, que deram origem a uma gens vigorosa, varonil, "cheia de juventude e coragem", capaz de transformar em "paulista", em filha da terra, a contribuição de todos os povos de além-mar (CARVALHO, 1972).

Menotti Del Picchia, entre os modernistas de São Paulo, é quem leva mais longe tal tipo de argumentação, enfeixando-a na metáfora dupla do "braço que trabalha" e do "cérebro que cria", do "pensamento", sob a égide de duas figuras mitológicas, Hércules e Apolo. Seu discurso constrói-se, freqüentemente, como uma somatória de negativas: o papel de São Paulo empreendedor é cantado e exaltado em sua unicidade, em contraposição a uma região geográfica atrasada - o Norte - e a uma série de fatores culturais, entre os quais avultam o regionalismo e o indianismo, como símbolo de um passado a ser negado e superado. Os termos utilizados não poderiam ser mais contundentes: São Paulo, Estado futurista por excelência- racial, industrial, econômica e culturalmente -, representa o "antípoda complexo dos cismarentos patrícios do norte, os quais ainda descansam, pacíficos, nas velhas normas ancestrais, sem as perturbações criadoras da concorrência do industrialismo insone, da batalha financeira americana."

A visão crítica do Norte como sinônimo do resto do Brasil, mergulhado num "carrancismo que anquilossa as nações secularmente cristalizadas em determinadas normas de vida", é especular ao combate sistemático contra estruturas culturais ultrapassadas, que traz em seu bojo a discussão sobre o surgimento de uma nova raça, cosmopolita e atualizada, profundamente diferente do tipo brasileiro convencional. Peri, Jeca-Tatu, "tíbios resquícios de uma minoria agonizante", estão fadados a desaparecer diante do surgimento do "tipo definitivo do brasileiro vencedor". "Novo Enéias da Roma americana", o brasileiro de São Paulo é um "ser poligenético, múltiplo, forte, vivo, culto, inteligente, audaz, fruto de muitas raças em combate, resultante de muitos sangues e adaptado, pela força das leis mesológicas, no meio em que surge, temperado pelo clima, plasmado pela força da 
fatalidade histórica; traz no seu organismo uma civilização multisecular, uma cultura requintada".

Se, em artigos como "Matemos Peri!" (Jornal do Comércio, 23 jan. 1921) e "Peri" (Correio Paulistano, 2 fev. 1921), Menotti Del Picchia está desfechando um ataque virulento contra "nosso absurdo e ingênuo amor pelo passado, que mata as aspirações de fórmulas novas - na política, na economia, na finança, na ética, na literatura -“, num texto como "Da Estética. Seremos Plagiários?”, sua tomada de posição revestese de conotações raciais. A questão central do artigo não é tanto o indianismo, que já fora denunciado por Monteiro Lobato como "decalque chateaubrianesco", mas o papel do índio na formação da cultura nacional, resumido pelo autor a "algumas tangas e tacapes" e a "alguns nomes sonoros de cobras, rios e cidades". A análise do caboclo pauta-se por critérios semelhantes: é definido como "uma crosta inconsciente, que se apatifa sob as ruínas das últimas taperas", votada ao desaparecimento.

Não é difícil perceber na visão negativa do índio e do caboclo ecos do pensamento de Monteiro Lobato, sobretudo do autor de Velha Praga e Urupês. Alguns exemplos serão suficientes para provar esta simetria. A partir da definição do índio como "ser errante" e do caboclo como "espécie de homem baldio, seminômade", Del Picchia e Lobato articulam um leque de questões que desemboca na falta de sentido estético como sinônimo de falta de cultura, numa atitude crítica. Um e outro mostram-se até mesmo incapazes de constituir condignamente sua moradia: a oca do índio "não valia a casa do castor, um João de barro era mais artista."; a palhoça do caboclo parece nascida do chão "por obra espontânea da natureza - se a natureza fosse capaz de criar coisas tão feias" e faz "gargalhar ao joão-de-barro". Que cultura poderiam criar tais seres? O índio "não deixou um traço estético no Brasil", nem na música (mero tan-tan), nem na literatura, nem na estatuária, do mesmo modo que o caboclo que, "egresso à regra", não apresenta "o mais remoto traço de um sentimento nascido com o troglodita".

Bastaria contrapor aos argumentos de Del Picchia a pesquisa de Rego Monteiro ${ }^{1}$ que, no mesmo período, forma sua visualidade nos exemplos da arte marajoara, conjugados com influências orientais (hindus, egípcias, japonesas), negando, portanto, um dos esteios de sua pregação. O discurso de Del Picchia, entretanto, persegue outros fins: construir uma imagem heróica da modernidade de São Paulo, usando toda sorte de recursos retóricos, não importa se nem sempre verdadeiros ou enfocados a partir de uma ótica peculiar. Em seu ataque aos resquícios do passado, romantismo, regionalismo, parnasianismo - o autor deixa transparecer uma concepção não apenas estética, mas social e racial.

Para negar o tripé racial brasileiro e para opor-lhe a visão do paulista cosmopolita, "homem de ação, pragmatista, ativo", Del Picchia não hesita em reduzir o problema das raças a uma convenção estereotipada, que confina o índio no museu e no livro de história, quando não na selva à espera de um Rondon, e o negro no interior do tipo caucasiano. Seus argumentos não poderiam ser mais explícitos quando define a hipótese do mestiço como um caso "raríssimo e quase teratológico", que "se descolora e se perde, vencido pela vitória fisiológica das raças fortes, que os navios de todo o mundo despejam nos nossos portos".

A operação não era gratuita. Embora com outros referenciais, era paralela ao "mito grego" dos parnasianos e à "correção parisiense" buscada pela sociedade da belle époque, denunciando o sonho do "Brasil branco" perseguido por nossas elites. O "tipo

\footnotetext{
${ }^{1}$ Sobre Vicente do Rego Monteiro, cf. Catálogo, Vicente do Rego Monteiro, 1899-1970; BATISTA, Lopez \& Lima, Brasil; primeiro tempo modernista, 1917/1929, pp.77-81, 94-5; sobre as dimensões estéticas e políticas do movimento das artes decorativas, cf. BOUILLON, Journal de Larte déco, 1903-1940; Arwas, Art déco.
} 
definitivo do brasileiro vencedor" alicerçava-se na morte de Peri e de Jeca-Tatu, na recusa de todo símbolo não-moderno. E não-modernos, segundo Cândido Mota Júnior, eram "o Brasil do selvagem antropófago, do aimoré todo plumas e dentuças humanas; o Brasil do miserável mestiço, inepto e indiferente a tudo, ao estado de sua gente, à integridade de sua pátria; o Brasil do mulato borracho, das mucamas sapecas, que só cuidam da pinga e das folias do tambu" (MOTA JUNIOR, 1921).

É no "mito tecnizado" que se explicita a visão positivista de São Paulo. A visão de uma cidade "cosmopolita - evoluída de séculos em cinqüenta anos de 'entradas' comovidas, onde se debatem, para amálgamas finais, canções de todos os idiomas, êxtases de todos os passados, generosidades e ímpetos de todas as migrações", na qual "formiga um povo multifário, internacional", fruto de uma raça que se transforma, dia a dia, " numa estirpe decidida e máscula, americanizada - ou melhor - abrasileirada pela luta de conquistas econômicas que a violência de um choque de nacionalidades e uma maior densidade de população exacerbaram”. Esta "luminosa metrópole, estuante de labor intelectual", "fatalizada a futurismos de atividades, de indústria, de história e de arte", " reconhecido leader mental da nação", é um fulcro gerador de "idéias e escolas", criador de expressões libertas das "velhas fórmulas perras" (ANDRADE, 1921).

Todos os ingredientes estão presentes nesta montagem multifacetada - considerações raciais e genéticas (o paulista, a multietnia), o momento histórico e o ambiente (a metrópole do século XX, a industrialização e seus corolários: urbanização, economia monetária, nova paisagem citadina, multidão), - convergindo na idéia de cultura como "sintoma", como "produto" da época e do lugar geográfico, que reponta na maioria dos textos até agora analisados.

Se toda autovisão é parcial, o mais das vezes, mítica, se tende a obliterar choques e contrastes para constituir uma imagem funcional, a análise de São
Paulo no momento em que surge com maior clareza aquilo que definimos um "mito tecnizado". Muitas vezes, entretanto, este é exterior ao grupo inovador, configura-se a partir de outras determinações, como testemunham os panegíricos de Carneiro Leão (LEÃO, 1920) e de Roberto Capri (CAPRI, 1922).

Algumas adjetivações usadas por Carneiro Leão - "atividade febril", "coragem" dos empreendimentos, "audácia realizadora"- são suficientes para mostrar que os atributos que os modernistas conferem à cidade não são exclusivos do grupo de vanguarda, mas participam de um estado de espírito bem mais amplo, encantado com o progresso alcançado por São Paulo num curto espaço de tempo. Ao exaltar seu crescimento demográfico, industrial, comercial, financeiro, educacional e cultural, o ensaísta não deixa de traçar uma linha de continuidade com o passado. Embora São Paulo seja a cidade que dá mais claramente a "sensação do crescimento de um povo", uma "criação exclusiva do trabalho e da inteligência", não pode ser considerada uma civilização parvenue, um acampamento de exploradores.

Se empreendimentos como a "Cultura Artística" e a Revista do Brasil são apontados como frutos típicos do solo paulistano Carneiro Leão, entretanto, confere primazia à área econômica e financeira como fulcro dos reais interesses da elite e do povo em geral, por constituírem "as razões dominantes da construção da fortuna pública e particular". Por isso, o povo paulista "lê e discute, com avidez e inteligência, os projetos, as medidas governamentais, as sugestões dos entendidos, dando-lhes o seu assentimento, ou criticando-lhes a execução". O realismo dos negócios é, porém, temperado pela sensibilidade latina, pela beleza natural da paisagem, constituindo um exemplo para a formação do "povo futuro", que o ensaísta faz brotar da mescla de italianos e brasileiros, da qual já estava resultando uma "raça forte, clara, ruidosamente alegre, que não pede senão viver e se expandir, com todo o viço e exuberância de belas criaturas, sequiosas de existir". 
A metrópole que Carneiro Leão descreve como "resultado exclusivo do esforço do homem", como exemplo da "força criadora do espírito humano", é considerada por Roberto Capri o germe de uma "verdadeira cidade-modelo" por seus monumentos, suas construções, suas "fábricas portentosas", por sua "vida intensa". Num tom sempre exaltatório da "Roma americana", o autor destaca tanto a urbe burguesa, com seus "prédios vastíssimos em os quais fervilha o lufa-lufa da Indústria, do Comércio, das Ciências, das Artes e das profissões liberais", quanto o núcleo proletário, tipificado pelo Brás, "pulmão industrial da cidade, onde o esforço do operário se multiplica grandiosamente num crescente esplêndido".

Embora o atendimento na loja fosse individualizado, o Mappin Stores não deixa de lançar mão de alguns dos mais poderosos instrumentos de venda dos magazines: catálogos ilustrados que permitem compras pelo correio ou por telefone; anúncios na imprensa diária, redigidos em vários idiomas, de acordo com o órgão de divulgação; vendas especiais em determinadas épocas do ano (Carnaval, Semana Santa, Natal, por exemplo); liquidações oportunamente anunciadas, que comprovam o alcance de uma "arte de viver", o triunfo da "aparência", forjados pelo comércio e transformados em normas pelas demais classes sociais, sobretudo pela pequena burguesia.

Como na Paris de Haussmann, constitui-se em São Paulo uma cidade opulenta, totalmente isolada do universo dos pobres, na qual Richard Morse percebe dois momentos distintivos. O primeiro, correspondente aos Campos Elíseos, é próprio de uma classe culta e afrancesada. Já o segundo, representado por Higienópolis, seria próprio de uma plutocracia "dinâmica, trabalhadora, endinheirada" e moldada na imagem anglo-saxônica de requinte e conforto. Tratar-seia da transição do baronato do café aos imigrantes enriquecidos, mas o lapso de tempo é por demais curto para que a hipótese de Morse possa ser pensada como efetiva (MORSE, 1970).
O crescimento horizontal de São Paulo confirma, porém, a idéia da "cidade tentacular", que a imaginação do povo aplica espontaneamente às linhas de bonde da Light, apelidadas "o polvo canadense" (AMERICANO, 1962, p.27).

Isso chama a atenção de inúmeros viajantes, entre os quais Artur Dias, que, em 1904, define São Paulo como "várias cidades sucessivamente agrupadas dentro da linha exterior instável". Mais severo é o juízo de Hesse-Wartegg em meados dos anos 10, que não hesita em escrever: "São Paulo não é uma grande cidade, mas um amontoado de pequenas cidades construídas uma ao lado da outra e uma dentro da outra, uma cidade que está em vias de se transformar em cidade grande e a única coisa grandiosa nela é o seu futuro". Tudo transpira o estado inacabado e a grandeza futura, até os homens, pois as relações sociais ainda são confusas, turvas, as águas não se clarificaram, os sedimentos ainda não se depositaram no fundo, as camadas ainda não se formaram (Apud AMERICANO, 1962).

O início do século XX testemunha ainda a introdução de novos índices de modernização na cidade: a abertura da primeira sala cinematográfica, Bijou, localizada na Avenida São João, e a concessão da chapa P-1 a Francisco Matarazzo, o qual entretanto, não é o primeiro dono de automobile do Estado.

A abertura da primeira sala cinematográfica, em novembro de 1907, não coincide com a introdução do cinema em São Paulo. Entre 1896 e 1899, houve 181 dias de projeções registradas, número baixo segundo Máximo Barro, se referindo à população da cidade e se comparado com os índices do Rio de Janeiro. O exemplo do Bijou é logo seguido por outros empresários: são abertas várias salas no centro e em bairros como Vila Buarque, Santa Ifigênia, Luz, Campos Elíseos, Brás, Liberdade, sem falar nas sessões cinematográficas gratuitas promovidas por algumas confeitarias de luxo (BARRO,1986, p.58). 
O uso do automóvel populariza-se aos poucos em virtude de seus preços elevados e de seu difícil manejo. Em 1904, são registrados oitenta e três veículos, que se transforma em dois mil e quinhentos no fim do primeiro quartel do século. Logo surgem leis regulamentando seu uso e São Paulo é o pioneiro nesse tipo de iniciativa: cobrança de taxa de circulação (1900), obrigatoriedade de inspeção pela prefeitura e fixação dos limites de velocidade (1903), carteira de habilitação (1904).

$\mathrm{O}$ incremento da produção verifica-se em dois setores: o agroexportador e o metalúrgico, que serão redimensionados com o término do conflito [Primeira Guerra Mundial]. No primeiro caso, a queda no consumo internacional de café é compensada pela demanda de carnes, cereais, feijão, açúcar e tecidos de algodão, que deveriam abastecer também o mercado do Rio de Janeiro, essencialmente importador. No segundo caso, trata-se da produção de peças e máquinas pelo sistema de retrabalho do metal por parte de pequenas empresas, que não podem ser consideradas indústrias, pois se voltavam principalmente para o conserto de equipamentos preexistentes.

A avaliação do momento é, porém, positiva, como testemunham alguns relatos já analisados, que nunca levam em conta a "questão operária" e a ascensão do movimento trabalhista, para não empanar o brilho do retrato sem defeitos. Mesmo se a eles contrapusermos a visão crítica de Lima Barreto, perceberemos que a equação se mantém, pois, em seu ataque à "calamitosa oligarquia paulista", o escritor carioca aponta logo aqueles elementos que se configuram como positivos na avaliação ufanista. O que Lima Barreto contesta - o "maléfico espírito de cupidez de riqueza com que São Paulo infeccionou o Brasil", o monopólio econômico do café, o imperialismo paulista "Não havia nada em São Paulo que não fosse excepcional. A alface de São Paulo era um regalo; os sapatos não faziam calos; os biscoutos curavam enxaquecas; os chapéus não deixavam crescer certos ornamentos conjugais; o dinheiro era excelente e os políticos... os mais sábios do mundo" - reponta, o mais das vezes, como "virtude" a explicar o caráter único da cidade e do Estado no contexto nacional (BARRETO, 1956, p.39, 52-55, 205).

Mas não é apenas na economia que São Paulo suscita admiração e entusiasmo. Clemenceau e Denis, escrevendo no mesmo período, destacam a função educacional da cidade: o primeiro, ao declarar que sua Escola Normal deveria servir de modelo aos países europeus; o segundo, ao defini-la "cérebro do Brasil" pelo valor de suas escolas e pela atenção dedicada ao ensino público, com exceção do secundário, quase todo em mãos de particulares (CLEMENCEAU,1911, p.246 e DENIS, s.d., p.174-149).

Se visitantes estrangeiros manifestam tamanho entusiasmo por certas características da cidade, não admira que, alguns anos depois este estado de espírito tome conta também da elite intelectual, que tentará traçar um painel positivo de sua vida cultural. Significativo é o testemunho de Goulart de Andrade que, em “Tristeza do Bem Alheio"(Correio Paulistano, 22 fev. 1920), à visão consagrada de São Paulo como reino do "juro, lucro, saque, cheque" opõe aquela de um verdadeiro renascimento intelectual, alicerçado em leitores, editores e, sobretudo, artistas por ele considerados "a plêiade de mais brilho que lucila por aî". Menotti Del Picchia, que, ao comentar o artigo, classificara a maioria do público paulista como pertencente ao "período da pedra lascada", em pronunciamentos posteriores não hesitará em afirmar a liderança exercida por São Paulo no país também em matéria de cultura: "É o Estado que mais lê, segundo se pode verificar pelas estratégias da casa editora do sr. Monteiro Lobato. É o Estado que discute seus artistas, aplaude-os, condena-os ao ostracismo do esquecimento. Exposições se abrem todos os dias, com mais ou menos sucesso. Glórias de atores e bailarinas caem, a golpes de vaias, nas suas ribaltas, ou se afirmam com a consagração dos seus aplausos. Canta óperas. Anima o Teatro 
Nacional" (HÉLIOS, 1920; DEL PICCHIA, 1920; ANDRADE, 1920).

Tem escultores magníficos, raros, mas fortes. Tem concertistas, pianistas geniais, virtuoses admiráveis. Nada falta a este retrato para desmentir a idéia de que São Paulo era dominado tão-somente pela "preocupação tacanha e prosaica da caça à moeda". O perfil bosquejado por Del Picchia pode ser enriquecido com os elementos que constam de uma crônica de Mário de Andrade, o qual percebe a cidade sob a ótica dupla do progresso material e intelectual. Fazem parte deste opostas facções - "tradicionalistas a convejar agouros" e "futuristas em fúria" -; igrejinhas, revistas, salões, onde a discussão é "larga e livre e a crítica isenta e sem desmaios", a geração de idéias e de escolas, "um ofego bíblico de criação", que faz prever "batalhas e sacrifícios geniais" (ANDRADE, 1920).

Alceu Amoroso Lima já havia traçado um prognóstico semelhante, ao afirmar: "o século XX é o século de São Paulo". Embora em seu artigo "O Êxodo" (Revista do Brasil, 17 set. 1917) proponha a saída dos grandes centros a fim de propiciar o desenvolvimento de um "nacionalismo agrário", o autor não deixa de reconhecer que em São Paulo brotaria o futuro movimento intelectual, alicerçado no "pleno germinar da idéia regionalista”. Se o regionalismo era combatido pelo futuro grupo de vanguarda, os outros elementos enumerados em "O Êxodo" não destoam do coro geral, na medida em que se referem a um Estado que desfruta metade da fortuna nacional e que possui uma aristocracia própria, herdeira da "altivez" e do "bom senso" dos bandeirantes.

A análise do ambiente cultural de São Paulo no período em pauta demonstra, porém, que a situação não era tão propícia quanto a descrita pelos modernistas e que nos encontramos, na realidade, diante de mais um aspecto do "mito tecnizado", tendente a fornecer uma imagem projetiva da cidade. Bastará, para tanto, examinar os dois campos principais de atuação do modernismo: o literário e o artístico.
A afirmação de que São Paulo é o Estado "onde mais se lê" deve ser relativizada diante dos índices de analfabetismo revelados pelo recenseamento de 1920: havia 72\% de iletrados no Estado, o que reduz drasticamente o espectro de um possível público consumidor. Embora tais dados sofressem uma redução significativa na capital, que contava com $42 \%$ de nãoalfabetizados, outros fatores são decisivos para estabelecer um perfil do público leitor: o preço das publicações, as preferências ostentadas, tiragens etc.

Os preços oscilavam de acordo com o tipo de publicação, mas as chamadas "edições populares" se situavam acima da média salarial da pequena burguesia, não conseguindo sustentar a concorrência dos periódicos. São estes, de fato, que se aproximam do gosto médio do público, propiciando-lhe um painel da atualidade que abarcava cultura, política, esporte, além de seções especializadas (moda, cozinha etc.). O tom mundano é o traço característico destas publicações, freqüentemente dirigidas à mulher como consumidora potencial, o que explica o surgimento de revistas marcadamente femininas ou de seções específicas nos periódicos gerais. A Vida Moderna (1907), A Cigarra (1914), A Garoa (1921), Vida Paulistana (1921), só para citarmos alguns títulos editados em São Paulo, oferecem a seus leitores "entretenimento" e "cultura" por contarem entre seus colaboradores com alguns dos mais renomados escritores nacionais.

No terreno propriamente literário, destaca-se $\mathrm{No}$ vela Semanal, lançada em 1921, com o propósito de "vulgarizar a melhor literatura", dirigindo-se simultaneamente a duas faixas de leitores: "homens de letras e pessoas cultas" e público "de mediana cultura". Compunha-se de contos, novelas, de um suplemento literário e pretendia, de fato, rivalizar com o livro "pela extensão, variedade e interesse da matéria".

Se o empreendimento da Sociedade Editora Olegário Ribeiro pode ser um índice de um certo tipo de gosto, não se pode esquecer um outro gênero determinante na época, o folhetim, publicado diariamente 
em órgãos da grande imprensa como $O$ Estado de $S$. Paulo. A maioria dos autores divulgados era estrangeira e entre eles se sobressaem os nomes de Dumas, Ponson du Terrail, Xavier de Montépin e Enrique Perez Escrich. A enumeração destes nomes já fornece um perfil do público leitor e, sobretudo, de seus gostos. Sucessos como os de Monteiro Lobato, Leo Vaz (O Professor Jeremias), Hilário Tácito (Mme. Pommery) são excessões no panorama literário, pois o público privilegiava aquilo que o primeiro denominava "romantismo do coração", ou comédias de costume ${ }^{2}$.

Se a paraliteratura é a tônica do período, isso não quer dizer que não existissem em São Paulo condições para o estabelecimento de um mercado produtor e consumidor com maiores ambições culturais. Monteiro Lobato é paradigmático neste sentido: sua casa editora não revoluciona apenas o sistema de distribuição, mas divulga alguns dos mais expressivos escritores nacionais, abrindo-se a outra áreas que não a literatura, como demonstra o exemplo de Oliveira Viana (VIANA, 1921, p.4).

No campo artístico, a situação era ainda mais imprecisa. Começava a se constituir um mercado de arte, mas, paradoxalmente, não existia um espaço específico que permitisse reconhecê-lo como tal.

Se definimos a visão que os modernistas fornecem de São Paulo como um "mito tecnizado" é porque ela é mais projetiva do que efetiva, sem que isso implique o não-reconhecimento do processo de modernização acelerado. Mas é justamente por ser acelerado que tal processo exibe tantos choques e contradições, obliterados na construção da épica da cidade, que leva em conta tão-somente seus aspectos positivos, coincidentes com as conquistas da burguesia

\footnotetext{
${ }^{1}$ Sobre o mercado editorial em São Paulo, vide SILVA BRITO, 155-159; HALLEWELL,L., O Livro no Brasil, São Paulo, 1985 , p. 235-265; e, sobretudo, FIORENTINO, T. A., Prosa de Ficção em São Paulo, São Paulo, 1982.
}

industrial e da plutocracia urbano-rural. Mesmo depois da Semana de Arte Moderna, mesmo depois da instalação do debate moderno, São Paulo continua sendo visto como um fruto da modernização "positiva" mais do que como resultado de um processo mais complexo, dialético e tenso. É o que transparece, à primeira vista, do poema que Blaise Cendrars escreveu para o catálogo da mostra parisiense de Tarsila do Amaral em 1926. Os versos finais são bem emblemáticos em sua celebração da "épica burguesa": São Paulo é visto como a concretização do ideal moderno por sua ausência de tradições e de preconceitos, por seu "apetite furioso", sua "confiança absoluta", seu "otimismo", sua "audácia”, seu "trabalho", seu "labor", sua "especulação", por sua preocupação exclusiva de "seguir as estatísticas prever o futuro o conforto a utilidade a mais-valia e atrair uma grande imigração".

A visão dos modernistas prolonga-se na percepção de Cendrars, que transforma São Paulo no epítome do espírito moderno, na concretização da "cidade futurista", ritmada pelo trânsito, pelas multidões, caracterizada por uma paisagem artificial, na qual soam buzinas e piscam letreiros. Mas há dois quistos "não-modernos" nesta paisagem: um fogareiro recortado numa lata de biscoitos e pequenos burros puxando carroças (Apud AMARAL, 1970, p.143), que remetem de imediato à complexidade da modernidade brasileira, contraditória, moderna e provinciana, milionária e excludente, com agudas tensões sociais, bem diferente das imagens do "mito tecnizado".

Blaise Cendrars aponta as facetas contraditórias, tensas e excludentes da modernização inacabada da paulicéia. Cendrars também faz referências à imagem de uma metrópole tomada integralmente pela pobreza, com uma enorme contingente de mão-de-obra instável, rotativa e flutuante, narrando os expedientes eventuais e incertos de sobrevivência das populações pobres.(PINTO, 1994, p.111). O poeta mostra como a sombra desse jogo imponente de aparências do cosmopolitismo burguês da Bèlle Époque, uma 
nova realidade surda e contundente ganhava corpo de forma tumultuária e tensa.

Era na "cidade", e no "centro" financeiro, comercial e administrativo que toda essa multidão de desempregados e semi-ocupados afluía (PINTO, 1994, p.184).

O que teria feito uma das personagens mais centrais, mais em foco, mais festejadas da vida artística de Paris e da Europa, decidir-se a vir a esse recanto remoto do mundo em 1925? Blaise Cendrars tinha uma obsessão: a modernidade. Ele era irresistivelmente atraído por todas as manifestações mais extremas do fenômeno moderno. Adolescente ainda foi testemunhar diretamente o erguimento dos arranhacéus em Nova York, vagando pelas ruas, enregelado e faminto, e pelo porto, o mais rico e movimentado do mundo, vendo chegar e partir cargas colossais de mercadorias e desembarcar falanges intermináveis de homens e mulheres vindos de todos os lados do planeta, despossuídos, andrajosos, mudos, agarrados uns aos outros com uma expressão de terror congelada nos olhos. Dali seguiu para a Califórnia, assistindo às corridas do ouro e do petróleo, observando cidades inteiras nascerem do dia para a noite, como cogumelos depois da chuva. Partiu para o Panamá, onde a engenharia acabara de unir os dois oceanos e onde se implantaram as mais delirantes operações especulativas jamais imaginadas. Voltou a Paris para publicar o Les pâques à New York, cujos manuscritos lidos por Apollinaire teriam uma influência decisiva na elaboração do seu Alcools. Ambos os livros publicados em 1913 revolucionariam a poesia francesa.

Depois da Guerra, com a morte de Apollinaire e o casal Delaunay fora de Paris, ele e Léger se tornaram as figuras-chaves da nova cena cultural. Por que então deixar Paris nesse momento e se deslocar para uma longínqua cidade do sul da América Latina? Mais do que uma simples visita, Blaise prolongaria sua estada por nove meses. Ele se sentiria magnetizado pela cidade, à qual voltaria três outras vezes, uma vez por ano, de 1926 a 1928, sempre para longas perma- nências. Ao que parece, múltiplas dimensões do fenômeno paulista o atraíam.

Não escapava, porém, a Blaise o outro lado desse fenômeno, mais imediato e concreto, a fantástica concentração de renda propiciada pela monocultura e pelas atividades especulativas que se desenvolviam em torno dela. Essa jogatina em escala mundial, esse teatro verde do poder fascinava igualmente o poeta. Em 1926, ele escreveu num apêndice ao seu romance Moravagine, publicado naquele ano:

28 de janeiro de 1924, em atravesso o Equador às 14 horas a bordo do Formose que me leva ao Brasil. Eu creio que agora estou preparado e posso levar uma vida dupla, uma vida de atividades febris, múltiplas, especulativas, arriscadas para ver o que significa dentre os homens pôr em movimento montes de dinheiro de um modo indiferente e gratuito e, por outro lado, levar uma vida lenta de escritor (BUHLER, 1960).

Mais tarde, noutro texto, ele se referiria ao Brasil como "o paraíso dos miliardários (SEVCENKO, 1990). Assim, Blaise pretendia penetrar profundamente nesse assomo que era a monocultura moderna, observando-a pelos seus pontos extremos: as mulheres e homens simples, os imigrantes pobres e angustiados num limite, o círculo estreito de onde saíam as decisões fixando o destino de milhões de seres no outro.

Paulo Prado, de que Blaise seria amigo e admirador até sua morte, proporcionou condições para que o poeta tivesse completa liberdade de movimento indo onde quisesse, fazendo o que gostasse. $\mathrm{O}$ poeta ou se enterrava nos sertões das fazendas dos Prado, ou perambulava pelas ruas e subúrbios de São Paulo, observando e conversando com as pessoas comuns. Quis ir ao Rio, quis ir às cidades históricas, subia sozinho às favelas, entrava nas cadeias, casebres, comia pelas ruas, fazia amizade com as quituteiras, feirantes, vendedores ambulantes e proprietários de pequenos negócios autônomos, de tostões (PINTO, 1994, p.115). 
Desde a chegada, Blaise se entrega à contemplação da cena brasileira, sem entusiasmo pelos intelectuais afrancesados que procuram se acercar dele, com exceção de Paulo Prado. Já na viagem de Santos para São Paulo, se desinteressara da comitiva de intelectuais que fora buscá-lo e se deixava hipnotizar pela suntuosidade da paisagem.

Blaise admira extasiado a Mata Atlântica, mas não a converte em símbolo, emblema ou alegoria. Ele goza a presença exuberante das plantas e árvores, o efeito conjunto da sua espessa cobertura sobre o relevo dramaticamente acidentado da serra, mas não faz dela uma representação abstrata que configure alguma identidade, força moral ou energia histórica. Assim também com olhos desprendidos de conceitos ele enxerga a cidade. Essa cidade que é uma mistura de Nice com Londres, os vastos jardins e espaços públicos de predominância mediterrânea: imigrantes e migrantes pobres de várias procedências, nacionalidades e etnias como italianos, sobretudo, portugueses, espanhóis, negros, mulatos, árabes. É importante observar que a cidade não era apenas formada pela diversidade dos aspectos materiais, segundo modelos de urbanização importados; a multiplicidade das presenças de vários povos e etnias também colaborava para formar seu perfil cosmopolita e desordenado (PINTO, 1996, p.418).

Essa colocação acerca do perfil de São Paulo, pode parecer contraditória e excludente, mas na verdade ela faz parte da ebulição íntima, da improvisação dos costumes e espelha a formação compósita, agregado mais ou menos informe de elementos de várias procedências, etnias, estratos que marcam o processo de sedimentação da sociedade paulistana nesse período de crescimento tumultuário, inspirando-nos na magistral análise de Sérgio Buarque de Holanda em “ Metais e Pedras Preciosas"(HOLANDA,1968,p.259) podemos afirmar que o que de tudo ressalta na sociedade paulistana é a "sua estrutura movediça que se desmancha, em partes, e se recompõe continuamen- te ao sabor de contingências imprevisíveis" (PINTO, 1996, p.415).

Como se observa, Blaise não precisa provar nada, não quer provar nada, apenas apreciar o frescor multifário de uma experiência social singular, intensa e heterogênea da modernidade contraditória em andamento (SALIBA, 1998, p.319). Do alto do seu quarto de hotel no Largo do Paissandu, ele observa o movimento embaixo. São notas curtas, instantâneos em que a linguagem procura registrar as imagens e o momento concreto quase com a imediatez mecânica e irrefletida com que o celulóide de Eastman registra a luz. A anotação social aparece pela escolha do foco que o poeta faz. "Paisagem".

O muro trespintado da PENSIONE MILANESE se enquadra na minha janela

Eu vejo uma fatia da avenida São João

Bondes carros bondes

Bondes-bondes bondes bondes

Mulas amarelas atreladas a três puxam carrocinhas vazias

Por cima das pimenteiras da avenida se desloca o anúncio gigante da CASA TOKIO

O sol verte verniz (BLAISE CENDRARS, 1985, p.56).

Nem falta o sarcasmo acre e bem-humorado, com que Blaise ridiculariza o uso espúrio que se faz do automóvel como um instrumento de ostentação, poder e opressão contra a população da cidade, conforme os versos sucessivos das composições "A cidade desperta" e "Klaxons elétricos".

Os primeiros bondes operários passam

Um homem vende jornais no meio da praça

As buzinas lhes respondem

E os primeiros carros passam a toda velocidade (BLAISE CENDRARS, 1985, p.61-2).

Aqui não se conhece a Liga do Silêncio

Como em todos os países novos

A alegria de viver e de ganhar dinheiro se exprime pela voz das buzinas e a peidorrada dos carros de escapamento abertos (BLAISE CENDRARS, 1985, p.62). 
Vagando pelos arrabaldes pobres, Blaise, o autor da Antologia negra e do balé de lendas africanas A criação do mundo, pôde constatar qual era a condição da população negra no Brasil e como renegados, estigmatizados, privados dos direitos elementares e excluídos da cena pública, eles estavam longe de ser heróis em São Paulo, e sobreviviam nas fímbrias da economia cafeeira. Em que pese a imagem tétrica, seu poema "Menu de bagatela" é de uma notável secura e impacto comunicativo, ressaltando pelo contraste fauve de cores e a luminosidade cegante uma cena que se fixa direto na memória como que impressa por um ferro em brasa.

O céu é de um azul cru

O muro em frente é de um branco cru

$\mathrm{O}$ sol cru bate na minha cabeça

Uma negra instalada num terracinho frita pequeninos peixes numa panela recortada de uma lata de biscoitos

Dois negrinhos roem um pedaço de cana-de-açucar (BLAISE CENDRARS, 1985, p.62).

Mas, apesar dos pesares, o poeta mantinha uma sólida confiança de que a experiência de São Paulo, levada às últimas conseqüências, pelas próprias tensões de extremos que comportava, pelas expectativas que irradiava, pelas potencialidades que latejavam nela lutando para se concretizar, acabaria gerando um elã democratizador que se provaria irreversível. Blaise parecia ver a cidade como um campo de prova, um grande laboratório urbano, em que a modernidade se redimisse das torpezas da Guerra e se justificasse como uma forma aglutinadora e emancipatória. Seu poema "Saint-Paul" é uma das descrições mais atiladas que já se fez da cena urbana, assim como do contexto social e cultural do experimento paulista.

\author{
Aqui nenhuma tradição \\ Nenhum preconceito \\ Nem antigo nem moderno \\ Só contam esse apetite furioso essa confiança absoluta \\ esse otimismo essa audácia esse trabalho esse esforço \\ essa especulação que faz construir dez casas por hora \\ de todos os estilos ridículos grotescos belos grandes pequenos \\ norte sul egípcio yankee cubista \\ Sem outra preocupação que a de seguir as estatísticas \\ prever o futuro o conforto a utilidade a mais-valia e \\ atrair uma enorme imigração \\ Todos os países \\ Todos os povos \\ Eu amo isso \\ As duas três velhas casas portuguesas que restam \\ são faianças azuis (BLAISE CENDRARS, 1985, p.63-4).
}

A estranha irregularidade desse poema é reveladora. O poema nos fala de amor, mas também de exploração desenfreada de pessoas, de esperanças, de ansiedades. Blaise vê esse fenômeno inédito de multidões heterogêneas - compostas de gente na maioria estranhas umas às outras - que se reuniram num ponto remoto do mundo, unidas apenas pela obsessão comum de forçar a realidade a adquirir a forma dos seus vários sonhos pessoais e obscuros. Mais do que cubista, essa era uma situação surrealista transformada num experimento social de escala assustadoramente grande. São Paulo era uma audaciosa obra de arte modernista em si mesma, com suas contradições intrínsecas, sua coleção de ambições delirantes e seu desprezo pela história, passada ou futura. Espalhadas dentro desse labirinto arquitetônico da metrópole, as poucas casas portuguesas remanescentes da vila colonial, pequenas, decorativas e antigas, eram tão inúteis quanto chalés sob uma avalanche. Elas poderiam, no entanto, servir ao menos como referência para se avaliar a dimensão do cataclismo moderno.

Eu adora esta cidade

São Paulo é como o meu coração 


\section{Bibliografia}

ANDRADE, Oswald de. "Reforma Literária". In: Jornal do Comércio, São Paulo, 19/05/1921.

ANDRADE, Mário de. "De São Paulo" In: Ilustração Brasileira. Dezembro, 1920

AMARAL, Amadeu. Blaise Cendrars no Brasil e os modernistas. São Paulo, 1970.

AMERICANO, Jorge. São Paulo nesse Tempo (1915-1935). São Paulo, 1962.

ARANHA, L. Cocktails. São Paulo: Brasiliense, 1984.

BARRETO, Lima. "A superstição do Doutor", "São Paulo e os Estrangeiros", "Bagatelas". "Marginália". São Paulo, 1956.

BARRO, M. "As Primeiras Projeções na Cidade de São Paulo". In: Filme Cultura. Rio de Janeiro, 08/1986.

BLAISE CENDRARS. Au coeur du monde: poésies complètes:19241929. Paris: Gallimard, 1985.

BUHLER, Jean. Blaise Cendrars, homme libre, poète au coeur du monde. Bienne, Éditions du Panorama, 1960.

CARVALHO, Ronald de. "Os Independentes de São Paulo". In: BATISTA, Rossetti M. et al, Brasil:1 Tempo Modernista 19/ 07/29. São Paulo, 1972.

CAPRI, Roberto. O Estado de São Paulo e o Centenário da Independência: o Comércio e a Indústria. São Paulo: Pocai \&Co, s.d.

São Paulo: A "Capital Artística” na comemoração do Centenário. São Paulo: Pocai \&Co.,1922.

CLEMENCEAU, G. Notes de voyage dans lAmeérique du Sud: Argentine, Uruguay, Brésil. Paris: Hachette, 1911.

DEL FIORENTINO, T. Prosa de ficção em São Paulo. São Paulo, 1982.

DEL PICCHIA, Menotti. "O Pintor Pedro Bruno". In: Correio Paulistano, 10 maio 1920.

DENIS, Pierre. O Brasil no século XX. Lisboa: José Bastos e Cia, s.d. FABRIS, Annateresa. O Futurismo Paulista. São Paulo, 1994.
HALLEWELL, L. O livro no Brasil, São Paulo, 1985. p. 235-265. HÉLIOS. "Gente Paulista”. In: Correio Paulistano, 29 dez. 1922. "Cérebro Paulista" In: Correio Paulistano, 23 fev. 1920.

HOLANDA, Sérgio Buarque de. "Metais e Pedras Preciosas". In: História Geral da Civilização Brasileira - A época Colonial. São Paulo: Difel, 1968.

LEÃO, A Caneiro. São Paulo em 1920. Rio de Janeiro: Annuário Americano, 1920.

MOTA JÚNIOR, Cândido. "A literatura Nacional” In: Jornal do Comércio, São Paulo, 3 out. 1921.

MORSE, Richard M. Formação Histórica de São Paulo (De comunidade à Metrópole). São Paulo: Difel, 1970.

PINTO, Maria Ines Machado Borges. Cotidiano e Sobrevivência: a vida do trabalhador pobre na cidade de São Paulo, 1890-1914. São Paulo: EDUSP, 1994.

"Urbanização Tumultuária e Plasticidade das Culturas Populares na Cidade de São Paulo (1890-1920)". In: América Latina Contemporânea: Desafios e Perspectivas. Iokoi, Z \& Dayre, E. (coord.). Rio de Janeiro: Expressão e Cultura/São Paulo: Edusp, 1996.

SALIBA, Elias Thomé. "A Dimensão Cômica da Vida Privada na República”. In: História da vida Privada no Brasil-República: da Belle Époque à Era do Rádio. São Paulo: Cia. das Letras, 1998.

SEVCENKO, Nicolau. "São Paulo, the quintessential uninhibited megalopolis as seen by Blaise Cendrars in the 1920s" - Conferência apresentada no XVII Congresso Internacional de Ciências Históricas, Madri, 1990.

Orfeu Extático na Metrópole: São Paulo, sociedade e cultura nos frementes anos 20. São Paulo: Cia. das Letras, 1992. VIANA, Oliveira. "Populações meridionais". OESP, 11 jun. 1921. 